\title{
PENGARUH MOTIF BERAFILIASI, KOMUNIKASI INTERPERSONAL DAN EFIKASI DIRI TERHADAP MOTIF BERPRESTASI MAHASISWA PROGRAM STUDI PENDIDIKAN SEJARAH FKIP UNSRI
}

\author{
${ }^{1}$ Hudaidah \\ ${ }^{1}$ Universitas Sriwijaya \\ hudai_hs@yahoo.co.id
}

\begin{abstract}
Abstrak
Kegiatan Penelitian ini dilakukan untuk mengetahui Pengaruh Motif Berafiliasi, Komunikasi interpersonal dan Efikasi Diri terhadap motif berprestasi Mahasiswa Program Studi Sejarah FKIP Unsri. Penelitian ini berbentuk studi pengaruh dengan menggunakan analisis regresi ganda untuk melihat pengaruh antar variabel penelitian. Penelitian dilakukan di Program Studi Sejarah FKIP Unsri tahun 2010 dengan jumlah sampel penelitian 52 orang mahasiswa. Berdasarkan hasil penelitian ini dapat disimpulkan yaitu : (1) motif berafiliasi berpengaruh secara signifikan terhadap motif berprestasi mahasiswa, (2) komunikasi interpersonal tidak berpengaruh secara signifikan terhadap motif berprestasi mahasiswa, (3) efikasi diri berpengaruh secara signifikan terhadapat motif berprestasi mahasiswa, dan (4) secara simultan motif berafilaisi, komunikasi interpersonal, efikasi diri berpengaruh terhadap motif berprestasi mahasiswa.
\end{abstract}

Kata Kunci : Motif, Berafilisi, Komunikasi Interpersonal, Efikasi Diri dan Prestasi.

\section{PENDAHULUAN}

Dalam diri mahasiswa selain adanya motif berafiliasi, maka harus memiliki kemampuan berkomunikasi yang disebut dengan komunikasi interpersonal. Komunikasi interpersonal ini adalah bagaimana cara seseorang yang telah memiliki motif berafiliasi mengaplikasikan motif berhubungan tersebut dengan cara berkomunikasi. Kemampuan berkomunikasi atau komunikasi interpersonal ini sangat penting karena sekalipun motif berafiliasi seseorang tinggi tetapi tanpa didukung kemampuan berkomunikasi sangat tidak memungkinkan,

Selain itu ada hal penting lain yang menghubungkan prilaku mahasiswa di kampus, yaitu efikasi diri/self efficacy yang berupa keyakinan seseorang akan kemampuannya untuk melaksanakan suatu tugas tertentu dengan berhasil. Self efficacy ini merupakan hal yang komplek dari pengetahuan, bahasa, sosial, keterampilan dan pengalaman. Kemampuan merupakan hal pokok dalam self efficacy. Menurut Bandura, kemampan hanya sebaik pelaksanaanya, orang sering gagal menunjukkan kenerjanya secara optimal walaupun mereka tahu dengan baik sekali apapun yang harus dilakukan 
Pengaruh Motif ..... - Hudaidah

dan keahlian yagn dimiliki, mereka tetap gagal melaksanakan kinerja secara optimal karena mereka meragukan kemampuannya untuk menggunakan keahlian itu dalam satu situasi tertentu (1997: 120).

Besarnya hubungan keyakinan pada kemampuan diri seorang mahasiswa akan mendorongnya untuk berprestasi, karena keyakinan pada kemampuan sendiri mempangaruhi motivasi pribadi, makin tinggi self efficacy, maka tingkat stess makin rendah, sebaliknya makin tinggi keyakian pada kemampuan sendiri, maka makin kokoh tekadnya untuk menyelesaikan tugas dengan baik, keyakian pada self-efficacy menghubungi tingkat tantangan dalam menyelesaikan tugas (Bandura, 1997: 121). Jika dihubungkan dengan motif berafiliasi diatas dengan self-efficacy ini saling berhubungan semakin tinggi self efficacy seseorang maka semakin percaya diri dalam bergaul. Di samping motif berafiliasi bentuk motif sosial lain yang hidup dalam masyarakat adalah motif berprestasi yaitu dorongan untuk mengatasi rintangan-rintangan dan memelihara kualitas kerja keras yang tinggi, bersaing melalui usaha untuk melebihi perbuatan yang lampau dan untuk mengungguli orang lain (Lidgren, 1973).

Penelitian ini bertujuan untuk mengungkap ada tidaknya pengaruh motif berafiliasi, komunikasi interpersonal dan efikasi diri terhadap motif berprestasi mahasiswa. Berpijak pada latar belakang dan masalah penelitian, hasil penelitian ini diharapkan dapat memberikan kontribusi yang berguna baik secara teoritik dan praktis. Dari segi teoritik hasil penelitian ini dapat memberikan sumbangan pada ilmu Sosiologi khususnya materi differensiasi sosial kaitannya dengan motif sosial dan kemajemukan sosial. Dari segi praktis hasil penelitian juga diharapkan bermanfaat bagi mahasiswa yaitu memberikan pengetahuan baru dan dapat meningkatkan motivasi belajar. Sehingga mampu mengembangkan diri menjadi mahasiswa yang berprestasi.

\section{METODE PENELITIAN}

Penelitian ini dilakukan di program studi pendidikan sejarah Universitas Sriwijaya (UNSRI) tahun 2010. Populasi penelitian adalah seluruh mahasiswa program studi Pendidikan Sejarah UNSRI dari semester satu s/d semester 11 berjumlah 155 orang mahasiswa. Sedangkan sampel penelitian diambil dengan menggunakan teknik acak sederhana dengan cara undian dimana akan diambil sebanyak $30 \%$ dari populasi yaitu sebanyak 52 mahasiswa sebagai sampel penelitian.

Data yang diperoleh akan dianalisis secara deskriptif dan inferensial. Analisis deskriptif dilakukan dengan tahapan yaitu penyajian data dengan tabel, penghitungan 
Pengaruh Motif ..... - Hudaidah

mean, median dan modus, simpangan baku, dan rentangan teoritik masing-masing variabel. Analisis infrensial untuk menguji hipotesis digunakan analisis regresi ganda, sebelumnya dilakukan uji persyaratan analisis data yaitu normalitas dan lineritas.

\section{HASIL DAN PEMBAHASAN}

\section{Hasil Penelitian}

Penelitian ini menggunakan teknik analisis regrisi ganda, analisis regresi ganda adalah suatu teknik analisis inferensial untuk menguji atau meramalkan ada tidaknya pengaruh tiga variabel bebas terhadap satu variabel terikat, yaitu motif berafiliasi $\left(\mathrm{X}_{1}\right)$, komunikasi interpersonal $\left(\mathrm{X}_{2}\right)$ dan efikasi diri $\left(\mathrm{X}_{3}\right)$ terhadap motif berprestasi mahasiswa( $\left.Y_{1}\right)$. Tujuan analisis regresi ganda ini adalah untuk membuktikan ada atau tidaknya hubungan fungsi atau pengaruh kausual dari variabel penelitian.

Untuk mengetahui hasil analisis regresi ganda dapat dilihat pada tabel berikut:

Tabel 1. Deskripsi tabel statistik analisis regresi ganda dengan SPPS VER 14

\begin{tabular}{|c|c|c|c|c|c|c|}
\hline \multirow{2}{*}{ No. } & \multirow{2}{*}{ Model } & \multicolumn{2}{|c|}{$\begin{array}{l}\text { Unstandardized } \\
\text { Coefficients }\end{array}$} & \multirow{2}{*}{$\begin{array}{c}\begin{array}{c}\text { Standardized } \\
\text { Coefficients }\end{array} \\
\text { Beta }\end{array}$} & \multirow[b]{2}{*}{$\mathrm{t}$} & \multirow[b]{2}{*}{ Sig. } \\
\hline & & B & $\begin{array}{l}\text { Std. } \\
\text { Error }\end{array}$ & & & \\
\hline & $\begin{array}{c}\text { (Constant } \\
\text { ) }\end{array}$ & $-12,584$ & 13,773 & &,- 914 & ,367 \\
\hline & $\mathrm{X} 1$ & ,648 & ,272 & ,395 & 2,381 &, 023 \\
\hline & $\mathrm{X} 2$ & ,337 & ,277 & , 177 & 1,216 & ,232 \\
\hline 4. & X3 & ,460 & ,200 & ,310 & 2,295 & ,028 \\
\hline
\end{tabular}

Sumber : Penghitungan data asli melalui spss ver.14

Adapun temuan dari penelitian ini selanjutnya dapat diuraikan sebagai berikut:

Terdapat pengaruh yang signifikan antara motif berafiliasi terhadap motif berprestasi mahasiswa.

Berdasarkan hasil analisis rengresi ganda diatas terlihat bahwa persamaan regresi untuk (X1) sebagai berikut:

$$
\hat{Y}=a+b_{1} X_{1}=-12,584+0,272 \mathrm{X}_{1}
$$

Konstanta sebesar $-12,587$ menyatakan bahwa jika tidak ada kenaikan nilai dari variabel (X1) motif berafiliasi, maka nilai motif berprestasi (Y) adalah -12,587. koefisien regresi sebesar 0,272 menyatkan bahwa setiap penambahan (karena tanda positif) satu skor atau nilai motif berafiliasi akan memberikan peningkatan skor sebesa 0,272 . 
Uji t untuk menguji taraf signifikansi konstanta dan variabel dependen motif berprestasi. Kreteria uji koefisien regresi dari variabel motif berafiliasi terhadap motif berprestasi. Dimana hipotesis yang diajukan yaitu Ha : Motif berafiliasi berpengaruh secara signifikan terhadap motif berprestasi mahasiswa, Ho : Motif berafiliasi tidak berpengaruh secara signifikan terhadap motif berprestasi mahasiswa. Dengan membandingkan thitung dengan $\mathrm{t}_{\text {tabel }}$ yaitu thitung $=2,381 \mathrm{t}_{\text {tabel }}$ diperoleh dari $(\mathrm{dk}=\mathrm{n}-3=$ $42-3=39$ ). Sehingga diperoleh $t_{\text {tabel }}=2,024$, jadi $t_{\text {hitung }}=2,381>t_{\text {tabel }}=2,024$ atau berdasarkan kolom sig. terdapat nilai 0,023 atau probabilitas jauh dibawah 0,05 , maka Ho ditolak. Sehingga dapat disimpulkan koefisien regresi signifikan atau motif berafiliasi benar-benar berpengaruh secara signifikan terhadap motif berprestasi mahasiswa.

\section{Terdapat pengaruh yang signifikan antara komunikasi interpersonal terhadap} motif berprestasi mahasiswa

Berdasarkan penghitungan diatas bahwa persamaan regresi (X2) sebagai berikut:

$$
\hat{Y}=a+b_{2} X_{2}=-12,584+0,277 \mathrm{X}_{2}
$$

Konstanta sebesar $-12,587$ menyatakan bahwa jika tidak ada kenaikan nilai dari variabel (X2) komunikasi interpersonal, maka nilai motif berprestasi (Y) adalah 12,587. Koefisien regresi sebesar 0, 277 menyatakan bahwa setiap penambahan (karena tanda positif) satu skor atau nilai komunikasi interpersonal akan memberikan peningkatan skor sebesa 0,277.

Uji t untuk menguji taraf signifikansi konstanta dan variabel dependen motif berprestasi . Kreteria uji koefisien regresi dari variabel komunikasi interpersonal terhadap motif berprestasi. Dimana hipotesis yang diajukan yaitu Ha : Komunikasi interpersonal berpengaruh secara signifikan terhadap motif berprestasi mahasiswa, Ho: Komunikasi interpersonal tidak berpengaruh secara signifikan terhadap motif berprestasi mahasiswa. Dengan membandingkan $t_{\text {hitung }}$ dengan $t_{\text {tabel }}$ yaitu $t_{\text {hitung }}=2,381$ $t_{\text {tabel }}$ diperoleh dari $(d k=n-3=42-3=39)$. Sehingga diperoleh $t_{\text {tabel }}=2,024$, jadi $t_{\text {hitung }}$ $=1,216>\mathrm{t}$ tabel $=2,024$ atau berdasarkan kolom sig. terdapat nilai 0,232 atau probabilitas jauh diatas 0,05 , maka Ho diterima. Sehingga dapat disimpulkan koefisien regresi tidak signifikan atau komunikasi interpersonal tidak berpengaruh secara signifikan terhadap motif berprestasi mahasiswa. 
Pengaruh Motif ..... - Hudaidah

\section{Terdapat pengaruh yang signifikan antara efikasi diri terhadap motif berprestasi mahasiswa}

Berdasarkan tabel penghitungan diatas terlihat bahwa persamaan regresi (X3) sebagai berikut:

$$
\hat{Y}=a+b_{3} X_{3}=-12,584+0,220 X_{3}
$$

Konstanta sebesar $-12,587$ menyatakan bahwa jika tidak ada kenaikan nilai dari variabel (X3) efikasi diri, maka nilai motif berprestasi (Y) adalah -12,587. Koefisien regresi sebesar 0,220 menyatakan bahwa setiap penambahan (karena tanda positif) satu skor atau nilai efikasi diri akan memberikan peningkatan skor sebesa 0,220.

Uji t untuk menguji taraf signifikansi konstanta dan variabel dependen motif berprestasi. Kreteria uji koefisien regresi dari variabel efikasi diri terhadap motif berprestasi. Dimana hipotesis yang diajukan yaitu Ha : efikasi diri berpengaruh secara signifikan terhadap motif berprestasi mahasiswa, Ho : efikasi diri tidak berpengaruh secara signifikan terhadap motif berprestasi mahasiswa. Dengan membandingkan $t_{\text {hitung }}$ dengan $t_{\text {tabel }}$ yaitu $t_{\text {hitung }}=2,295 t_{\text {tabel }}$ diperoleh dari $(\mathrm{dk}=\mathrm{n}-3=42-3=39)$ Sehingga diperoleh $\mathrm{t}_{\text {tabel }}=2,024$, jadi $\mathrm{t}_{\text {hitung }}=2,295>\mathrm{t}_{\text {tabel }}=2,024$ atau berdasarkan kolom sig. terdapat nilai 0,028 atau probabilitas jauh dibawah 0,05, maka Ho ditolak. Sehingga dapat disimpulkan koefisien regresi signifikan atau efikasi diri benar-benar berpengaruh secara signifikan terhadap motif berprestasi mahasiswa.

\section{Terdapat pengaruh yang signifikan antara motif berafiliasi, komunikasi interpersonal, dan efikasi diri secara simultan terhadap motif berprestasi mahasiswa}

Berdasarkan hasil penghitugan diatas terlihat bahwa persamaan regresi (X1, X2, X3) sebagai berikut ;

$$
\hat{Y}=a+b_{1} X_{1}+b_{2} X_{2}+b_{3} X_{3}=-12,584+0,272 X_{1}+0,277 X_{2}+0,220 X_{3}
$$

Berdasarkan penghitungan uji Anova atau $F_{\text {tes }}$ diperoleh $F_{\text {hitung }}$ sebesar 16,685 dengan taraf signifikansi 0,000 karena probabilitas jauh dibawah 0,05, maka model regresi dapat dipakai untuk mempresiksi motif berprestasi mahasiswa. Untuk menguji signifikansi motif berafiliasi, komunikasi interpersonal dan efikasi diri secara simultan terhadap motif berprestasi sebagai berikut:

Kaidah pengujian signifikansi regresi ganda 
Pengaruh Motif ..... - Hudaidah

Jika $F_{\text {hitung }}>F_{\text {tabel, }}$ maka signifikan

Jika $F_{\text {hitung }}<F_{\text {tabel, }}$ maka tidak signifikan

Berdasarkan penghitungan diperoleh $\mathrm{F}_{\text {hitung }}=16,685>\mathrm{F}_{\text {tabel }}=2,85$, maka dapat disimpulkan bahwa motif berafiliasi, komunikasi interpersonal, dan efikasi diri secara simultan benar-benar berpengaruh signifikan terhadap motif berprestasi mahasiswa.

\section{Pembahasan}

Pembahasan penelitian ini diarahkan dengan melihat hasil pengujian analisis regresi ganda yang telah dilakukan dan diuraikan diatas. Uraian selengkapnya adalah sebagai berikut :

\section{Motif berafiliasi berpengaruh secara signifikan terhadap motif berprestasi mahasiswa.}

Motif berafiliasi adalah motif yang mendorong pembentukan dan pertahanan hubungan positif dengan orang lain, dengan keinginan untuk disukai dan untuk diterima (Atkinson, 1958). Lindgren (1973) mendeskripsikan motif berafiliasi sebagai suatu kebutuhan yang dekat dengan sikap sosial yaitu kebutuhan untuk berinteraksi dengan orang lain, terutama dengan kelompoknya, menyenangkan orang lain, menunjukkan afeksi kepada orang lain dan menjaga loyalitas terhadap keluarga dan teman-teman.

Dalam melakukan hubungan sosial, hal pertama yang perlu dilakukan adalah membina rasa saling percaya satu sama lain. Menurut Herb Gohen, orang yang memberi kepercayaan pada orang lain maka dia akan dipercaya orang lain. Apabila seseorang menunjukkan kepercayaan pada orang lain dan bersikap jujur, maka orang lain akan lebih terbuka dan percaya dengan kita. Seseorang akan menikmati pembicaraan apabila dia percaya dengan kita. Dalam melakukan hubungan sosial, kita perlu menanamkan rasa saling ketergantungan atau rasa saling terikat dengan orang lain. Orang yang mempunyai hubungan sosial yang baik, maka ia mampu membuat dirinya bermanfaat bagi orang lain. Orang yang mampu berhubungan sosial dengan orang lain maka orang tersebut telah mencapai $85 \%$ dalam mengatasi kesulitan dalam pekerjaan dan $99 \%$ mencapai keberhasilan dalam kehidupan pribadi. (Mulyani, 2008).

Orang yang mempunyai motif berafiliasi tinggi mempunyai dorongan untuk membuat hubungan dengan orang lain, karena ada keinginan untuk disukai dan untuk diterima dan akan selalu berusaha supaya hubungan tersebut tetap ada. Berdasarkan hasil penelitian hudaidah (2004) menunjukkan bahwa siswa dengan hasil belajar baik 
Pengaruh Motif ..... - Hudaidah

memiliki teman-teman dengan nilai yang baik pula atau siswa dengan motif berafiliasi tinggi menunjukkan hasil belajar yang baik.

Berdasarkan penelitian ini yang dilakukan pada mahasiswa Program Studi sejarah FKIP Unsri bahwa terbukti secara signifikann motif berafiliasi berpengaruh terhadap motif berprestasi mahasiswa. Motif berafiliasi secara kuat atau tinggi mempengaruhi motif berprestasi mahasiswa. Terlihat dari uji regresi ganda yang telah dilakukan dimana $\mathrm{t}_{\text {tabel }}=2,024$, jadi $\mathrm{t}_{\text {hitung }}=2,381>\mathrm{t}_{\text {tabel }}=2,024$. Hal ini terjadi karena motif berafiliasi ini adalah motif yang mendorong mahasiswa untuk bergaul dengan orang lain, semakin baik seorang bergaul menunjukkan kemampuannya dalam menjalankan kehidupan sosialnya. Sejalan dengan itu berdasarkan pendapat Maslow bahwa kebutuhan manusia tingkat kedua yaitu kebutuhan akan cinta kasih, ciri utama kebutuhan ini adalah keinginan untuk menjaga hubungan baik dengan orang lain. Apabila kebutuhan ini terpenuhi maka merupakan kemampuan sosial seseorang (Woolkfork: 2004).

Mahasiswa dengan motif berafiliasi tinggi berdasarkan pengamatan juga terlihat bahwa mereka cendreung untuk memilih-milih teman dan berbuat terbaik untuk teman-teman terdekatnya. Contohnya mahasiwa dengan IPK tinggi biasanya memiliki teman-teman dengan nilai yang tinggi pula, dan kelompok ini sepertinya cenderung bergaul untuk meningkatkan prestasi mereka. Hal ini mungkin sejalan dengan kata pepatah nenek moyang kita jika bergaul dengan orang baik kita bisa menjadi baik atau sebaliknya.

\section{Komunikasi interpersonal tidak berpengaruh secara signifikan terhadap motif berprestasi mahasiswa}

Haviland (dalam Mulyana, 2001) mengatakan bahwa komunikasi adalah proses yang memungkinkan seseorang (komunikator) menyampaikan rangsangan (biasanya lambang-lambang verbal) untuk mengubah perilaku orang lain (Communicate). De Vito (1995) mengemukakan komunikasi interpersonal adalah komunikasi yang mengambil tempat antara dua orang yang memiliki hubungan yang tidak bisa dipungkiri. Sedangkan Barnlund (dalam Wiryanto, 2006) komunikasi antar pribadi diartikan sebagai pertemuan antara dua, tiga, atau mungkin empat orang, yang terjadi sangat spontan dan tidak berstruktur. Komunikasi interpersonal adalah komunikasi antara dua orang dalam interaksi tatap muka yang semua orang dapat menangkap reaksi orang lain secara verbal maupun nonverbal. 
Pengaruh Motif ..... - Hudaidah

Berdasarkan hasil penelitian dalam skripsi Ernawati (2008) yang bertujuan melihat hubungan komunikasi interpersonal mahasiswa dan dosen dengan prestasi akademik mahasiswa, diketahui bahwa komunikasi interpersonal tinggi berkorelasi positif dengan prestasi akademik. Ernawati menyimpulkan bahwa semakin tinggi komunikasi interpersonal semakin tinggi prestasi belajarnya semakin rendah komunikasi interpersonalnya semakin rendah prestasi belajarnya. Hasil penelitian ini tidak sesuai dengan teori sebelumnya yang menyatakan semakin tinggi komunikasi interpersonal semakin tinggi prestasi belajar dan semakin rendah komunikasi interpersonalnya semakin rendah prestasi belajarnya. Berdasarkan hasil penelitian ini tidak terbukti adanya pengaruh komunikasi interpersonal terhadap motif berprestasi mahasiswa, dan korelasinyapun menunjukan hubungan yang cukup diantara kedua variabel.

Pada dasarnya komunikasi yang efektif ditandai dengan hubungan sosial yang baik. Komunikasi interpersonal dinyatakan efektif bila pertemuan komunikasi merupakan hal yang menyenangkan bagi komunikan. Bila kita berkumpul dengan orang yang menyenangkan maka akan terjadi komunikasi yang menyenangkan. Setiap melakukan komunikasi interpersonal, kita tidak hanya sekedar menyampaikan isi pesan, tetapi juga menentukan kadar hubungan interpersonal terebut. Semakin dekat hubungan antar komunikan semakin efektif komunikasi interpersonal diantara mereka.

Berdasarkan pengamatan pada mahasiswa yang terjadi di lingkungan kampus, komunikasi interpersonal secara keseluruhan diantara mereka tidak terjalin antar kelompok saja. Sehingga komunikasi interpersonal antar mahasiswa secara keseluruhan tidak terjalin efektif. Hal ini didukung pula dengan pernyataan mahasiwa bahwa komunikasi interpersonal tidak terjalin begitu efektif diantara mereka karena adanya group-group yang terbentuk. Penyebab lain tidak terbuktinya secara signifikan variabel komunikasi interpersonal terhaddap motif berprestasi masasiswa, karena kuesioner komunikasi interpersonal yang disusun oleh peneliti masih bersifat umum, sehingga perlu dibentuk model angket komunikasi interpersonal yang lebih khusus dan berkaitan langsung dengan motif berprestasi mahasiswa.

\section{Efikasi diri berpengaruh secara signifikan terhadap motif berprestasi mahasiswa}

Bandura (1997) menyatakan bahwa efikasi diri adalah keyakinan seseorang terhadap kemampuan dirinya untuk melakukan sesuatu pekerjaan dan mendapatkan prestasi tertentu. Lebih lanjut Bandura menyatakan bahwa efikasi diri akan menentukan cara seseorang untuk berpikir, bertindak dan memotivasi diri mereka menghadapi 
Pengaruh Motif ..... - Hudaidah

kesulitan dan permasalahan. Sukses atau gagalnya seseorang ketika melakukan tugas tertentu ditentukan oleh efikasi dirinya. Orang yang memiliki efikasi diri yang tinggi akan bisa menghadapi kegagalan dan hambatan yang mereka hadapi, stabil emosinya, bersikap dan memiliki internal locus of control yang tinggi. Chomie (2003) menjelaskan bahwa efikasi diri mempengaruhi kepercayaan seseorang pada tercapai atau tidaknya tujuan yang sudah ditetapkan. Lebih lanjut Chomie menyatakan bahwa efikasi diri yang positif adalah keyakinan seseorang bahwa ia mampu mencapai pekerjaan atau prestasi yang diinginkannya. Tanpa adanya efikasi diri seseorang tidak akan memiliki keinginan untuk melakukan perilaku tertentu.

Individu dengan efikasi diri tinggi memiliki komitmen dalam memecahkan masalahnya dan tidak akan menyerah ketika menemukan bahwa strategi yang sedang digunakan itu tidak berhasil. Menurut Bandura (1991), individu yang memiliki efikasi diri yang tinggi akan sangat mudah dalam menghadapi tantangan. Individu tidak merasa ragu karena ia memiliki kepercayaan yang penuh dengan kemampuan dirinya. Individu ini akan cepat menghadapi masalah dan mampu bangkit dari kegagalan yang ia alami. Hal ini berbanding lurus dengan hasil penelitian dari Scapinello dalam menunjukkan bahwa seseorang dengan tingkat kebutuhan akan prestasi yang tinggi kurang dapat menerima kegagalan daripada mereka dengan kebutuhan akan prestasi rendah. Mahasiswa dengan efikasi diri tinggi berusaha untuk tidak gagal dalam studinya dan berusaha keras untuk itu.

Melalui penelitian ini berdasarkan hasil analisisnya menunjukan bahwa efikasi diri secara signifikan berpengaruh terhadap motif berprestasi mahasiswa, sehingga penelitian ini secara tidak langsung mendukung beberapa teori yang menyatakan bahwa orang dengan efikasi diri tinggri cenderung memiliki motivasi berprestasi yang tinggi pula. Berdasarkan pengamatan dalam pembelajaran juga menunjukkan mahasiswa dengan efikasi diri tinggi cenderung lebih percaya diri dalam mengikuti proses pembelajaran dan prestasi akademik merekapun cenderung tinggi. Kepercayaan diri yang dimiliki menyebabkan mahasiswa mampu membangkitkan motivasi dan berbagai potensi yang dimilikinya untuk dapat mengerjakan berbagai tugas perkuliahan.

\section{Motif berafiliasi, komunikasi interpersonal dan efikasi diri secara simultan berpengaruh signifikan terhadap motif berprestasi mahasiswa}

Seseorang melakukan hubungan sosial, perlu menanamkan rasa saling ketergantungan atau rasa saling terikat dengan orang lain. Orang yang mempunyai hubungan sosial yang baik, maka ia mampu membuat dirinya bermanfaat bagi orang 
Pengaruh Motif ..... - Hudaidah

lain. Orang yang mampu berhubungan sosial dengan orang lain maka orang tersebut telah mencapai $85 \%$ dalam mengatasi kesulitan dalam pekerjaan dan $99 \%$ mencapai keberhasilan dalam kehidupan pribadi (Wahyuni, 2008). Mahasiswa yang memiliki motif berafiliasi tinggi cenderung mampu membina hubungan sosial yang baik dengan sesama teman. Hubungan yang dijalin berdasarkan kedekatan ini mempengaruhi keinginan mereka untuk meningkatkan prestasi. Motif memilih teman dekat biasanya dihubungkan dengan kegiatan perkuliahan, sehingga terlihat kecenderungan mahasiswa membina afiliasi mereka berdasarkan kepentingan perkuliahan. Mahasiswa dengan prestasi tinggi lebih banyak berhubungan dengan sesama mereka dan saling mengisi diantara mereka.

Komunikasi interpersonal adalah komunikasi yang dijalin seseorang dengan orang lain. Baik dalam bentuk menerima maupun menyampaikan informasi. Komunikasi interpersonal ini merupakan kemampuan yang dimiliki seseorang dalam kehidupan sosialnya, baiknya kemampuan berkomunikasi secara interpersonal menunjukkan sesorang memiliki kemampuan dalam berkomunikasi. Selain itu Komunikasi yang efektif ditandai dengan hubungan sosial yang baik. Komunikasi interpersonal dinyatakan efektif bila pertemuan komunikasi merupakan hal yang menyenangkan bagi komunikan. Bila kita berkumpul dengan orang yang menyenangkan maka akan terjadi komunikasi yang menyenangkan. Setiap melakukan komunikasi interpersonal, kita tidak hanya sekedar menyampaikan isi pesan, tetapi juga menentukan kadar hubungan interpersonal. Berdasarkan tingkat korelasi antara komunikasi interpersonal dengan motif berprestasi mahasiswa menunjukan adanya hubungan pada taraf cukup kuat.

Keyakinan pada kemampuan sendiri menghubungkan motivasi pribadi, makin tinggi self-efficacy, maka tingkat stress makin rendah, sebaliknya makin tinggi keyakinan pada kemampuan sendiri, maka makin kokoh tekadnya untuk menyelesaikan tugas dengan baik, keyakinan pada self-efficacy menghubungkan tingkat tantangan dalam menyelesaikan tugas individu dengan efikasi diri tinggi memiliki komitmen dalam memecahkan masalahnya dan tidak akan menyerah ketika menemukan bahwa strategi yang sedang digunakan itu tidak berhasil. Menurut Bandura (1991), individu yang memiliki efikasi diri yang tinggi akan sangat mudah dalam menghadapi tantangan. Individu tidak merasa ragu karena ia memiliki kepercayaan yang penuh dengan kemampuan dirinya. Individu ini akan cepat menghadapi masalah dan mampu bangkit dari kegagalan yang dialami. Dengan demikian efikasi diri berpengaruh terhadap motif 
berprestasi mahasiswa. Mahasiswa dengan efikasi diri tinggi cenderung bertekad menyelesaikan tugas perkuliahan dengan baik. Menyelesaikan tugas dengan baik merupakan ciri dari motif berprestasi tinggi.

Mahasiswa dalam menjalankan perkuliahannya dipengaruh oleh dua faktor yaitu faktor ekternal dan internal. Faktor eksternal berhubungan langsung dengan kehidupan sosial mereka, dalam kehidupan sosial mereka membutuhkan orang lain. Kebutuhan akan orang berhubungan langsung dengan motif bergaul/berafiliasi mahasiswa, dan bagaimana mereka menjalin pergaulan tersebut dengan kemampuan berkomunikasi yang baik/ komunikasi interpersoanal. Sedangkan faktor internal salah satunya adalah efikasi diri yaitu kepercayaan pada kemampuan yang dimilikinya.

Penelitian ini menunjukan secara simultan motif berafiliasi, komunikasi interpersonal dan efikasi diri berpengaruh pada motif berprestasi mahasiswa. Terbukti dengan hasil analisis yang menunjukkan $F_{\text {hitung }}=16,685>F_{\text {tabel }}=2,85$. Artinya mahasiswa yang memiliki motif berafiliasi, komunikasi interpersonal dan efikasi diri berpengaruh secara signifikan terhadap motif berprestasi mereka. Pembahasan merupakan bagian terpenting dari suatu penelitian. Pada bagian inilah sebenarnya ketajaman atau kemampuan peneliti akan tampak. Bagian ini berisi analisis secara teoritik dari peneliti terhadap hasil penelitian. Jadi bagian ini merupakan telaah dari peneliti terhadap hasil penelitian. Telaah ini mengacu pada teori dan pendapat para ahli dan pendapat peneliti sendiri.

\section{KESIMPULAN}

Berdasarkan hasil penelitian yang telah dijabarkan diatas dapat disimulkan halhal sebagai berikut:

a. Motif berafiliasi berpengaruh secara signifikan terhadap motif berprestasi mahasiswa. Motif berafiliasi secara kuat atau tinggi mempengaruhi motif berprestasi mahasiswa. Terlihat dari uji regresi ganda yang telah dilakukan dimana, jadi $\mathrm{t}_{\text {hitung }}=2,381>\mathrm{t}_{\text {tabel }}=2,024$.

b. Komunikasi interpersonal tidak berpengaruh secara signifikan terhadap motif berprestasi mahasiswa. Terlihat dari hasil analisis regresi yang telah dilakukan dimana, $t_{\text {hitung }}=1,216>\mathrm{t}_{\text {tabel }}=2,024$.

c. Efikasi diri secara signifikan berpengaruh terhadap motif berprestasi mahasiswa. Terlihat dari hasil analisis regresi ganda terlihat, jadi $\mathrm{t}_{\text {hitung }}=2,295>\mathrm{t}_{\text {tabel }}=$ 2,024 . 
d. Motif berafiliasi, komunikasi interpersonal dan efikasi diri berpengaruh secara simultan pada motif berprestasi mahasiswa. Terbukti dengan hasil analisis yang menunjukkan $\mathrm{F}_{\text {hitung }}=16,685>\mathrm{F}_{\text {tabel }}=2,85$.

\section{DAFTAR PUSTAKA}

Alfiandra. 2004. "Prasangka Rasial dan Bentuk Hubungan dalam Suatu Proses Integrasi antara Masyarakat Jawa dengan Masyarakat Keturunan Cina di Kota Yogyakarta dan Kota Surakarta”. Tesis (Tidak Dipublikasikan). Yogyakarta: Program Pasca Sarjana Universitas Gadjah Mada.

Atkison, 1958. Motives In Fantasy, Action and Society, New York: Van Mostrand.

Bandura, A. 1991. Self-efficacy Mechanism in Physiological Activation and HealthPromoting Behavior. In J. Madden, IV (Ed.). New York: Raven.

Bandura, A. 1991. Self-regulation of motivation through anticipatory and selfregulatory mechanisms. In $R$. A. Dienstbier (Ed.), Perspectives on motivation: Nebraska symposium on motivation (Vol. 38, pp. 69-164). Lincoln: University of Nebraska Press.

Bandura, A. 1997. Self-efficacy: The Exercise of Control. New York: Worth Publishers.

Cangara, H. 2003. Pengantar Ilmu Komunikasi. Jakarta: PT. Raja Grafindo persada

Cofer and Apply, 1964. Motivation: Theory and Research, New York: Willey.

De Vito, J. 1995. The Interpersonal Communication Book. Sevent Organisasi. Cetakan Kedua. Jakarta: Bumi Aksara.

Ernawati, 2008. "Hubungan Komunikasi Interpersonal antara Mahasiswa dan Dosen Dengan Prestasi Akademik Mahasisawa Fakultas Psikologi Universitas Gunadarma, Skripsi (Tidak Dipublikasikan). Jakarta: Fakultas Psikologi Universitas Gunadarma.

Heckhausen, H. 1980. Motivation dan Handlen. Berlin: Springer Verlag.

Hermans H. 1967, Motivation dan Prestitie. Amsterdam: Swezt Zeidlinger.

Hudaidah. 2004. Analisis Motif Berafiliasi dan Berprestasi Pelajar Pribumi dan Keturunan Cina di Kota Palembang. Palembang: Jurusan Pendidikan Sejarah FKIP UNSRI.

Issac, Harold, 1993. Pemuja Terhadap Kelompok Etnis. Identitas Kelompok dan Perubahan Politik. Jakarta: Yayasan Obor.

Kukla, A. 1972. Attributional Determinants of Achievment-Related Behavior, Jurnal Of Personality and Social Psychology No. 21. 
Pengaruh Motif ..... - Hudaidah

Le Vine. 1977. “Child Rearing of Cultural Adaption” dalam Leiderman Rosenfield (ed) Culture. New York: Ang Intancy Academic Press.

Martina, Sri Mulyani. 1984. Motif Sosial. Yogyakarta: Gadjah Mada University Press.

Matsushima, R., \& Chiomi, K., 2003. Social Self-Efficacy and Interpersonal Stress in Adolescence. Social Behavior and Personality.

Muhidin dan Somantri. 2006. Aplikasi Statistika Dalam Penelitian. Bandung: Pustaka Setia

Mulyana, D. 2001. Ilmu Komunikasi Suatu Pengantar. Cetakan Ketiga. Bandung: PT. Remaja

Mulyani, Analisis Pengaruh Faktor-Faktor Kecerdasan Emosi Terhadap Komunikasi Interpersonal Perawat dengan Pasien di Unit Rawat Inap Rsjd Dr. Amino Gondohutomo Semarang Tahun 2008. Tesis (Tidak Dipublikasikan). Semarang: Program Pascasarjana Undip.

Murray. 1938. Exploration in Personality. New York: Oxpord Universit Press.

Nasution, Noehi. 1992. Psikologi Pendidikan. Jakarta: PPTK DEPDIKBUD.

Nurdin, Syfruddin. 2005. Model Pembelajaran yang Memperhatikan Keragaman Individu Siswa Dalam Kurikulum Berbasis Kompetensi. Jakarta: Rajawali Pers.

Paulus, Budihardjo. 1997. Mengenal Teori Kepribadian Mutakhir. Yogyakarta: Kanisius.

Riduan dan Sunarto, 2009. Pengantar Statistik Untuk Penelitian Pendidikan, Sosial, Ekonomi, Komunikasi, dan Bisnis, Bandung: Alfhabeta.

Schwarzer, R. (Ed.). 1992. Self-efficacy: Thought Control of Action. Washington: Hemisphere.

Slavin, R. 1997. Educational Psyscology Theory and Practice, Four Edition. Massachussets: Allyn and Bacon Publisher.

Wiryanto. 2006. Pengantar Ilmu Komunikasi. Cetakan Ketiga. Jakarta: PT. Gramedia. Woolfolk, Anita.2004. Educational Psychology. Ohio: Pearson. 